\title{
Polyglactin 910 (Vicryl Rapide) for Reducing Pain and Wounds Healing in Postpartum Perineum
}

\author{
Polyglactin 910 (Vicryl Rapide) untuk Mengurangi Nyeri dan Mempercepat \\ Penyembuhan Luka pada Perineum Postpartum
}

\author{
Amilya Pradita, Abkar Raden, Farida Kartini \\ Faculty of Health Science Universitas Aisyiyah \\ Yogyakarta
}

\begin{abstract}
Objective: The purpose of this study was to compare the use of polyglactin 910 (vicryrapide) and chromic catgut to perineal pain and healing wounds on postpartum.

Methods: This research is true experiment with a randomized controlled trial (RCT) and single-blind. The number of respondents pad this study of 40 respondents were divided into 20 respondents to the intervention group (vicrylrapide) and 20 respondents for the control group (chromic catgut). Data analysis using independent t-test.

Result: Statistical test results using independent t-test for pain showed $p=0.035<0.05$ and for wound healing showed $p=0.000<0.05$ of a second can mean the results are there differences in the use of threads polyglactin 910 (vicrylrapide) and chromic catgut thread to perineal pain and healing wounds in the mother postpartum perineum.
\end{abstract}

Conclusions: The use rapidevicryl thread to repair perineal perineum or stitches can reduce perineal pain and healing wounds better than the use of the chromic catgut thread.

Keywords: chromic catgut, pain, polyglactin 910, rapide vicryl, wound healing of the perineum.

\begin{abstract}
Abstrak
Tujuan: Untuk mengetahui perbandingan penggunaan polyglactin 910 (vicry rapide) dan chromic catgut terhadap nyeri dan penyembuhan luka perineum pada postpartum.
\end{abstract}

Metode: Penelitian ini merupakan penelitian true experiment dengan randomized controlled trial (RCT) dansingle blind. Jumlah responden pada penelitian ini sebanyak 40 responden yang di bagi menjadi 20 responden untuk kelompok intervensi (vicryl rapide) dan 20 responden untuk kelompok kontrol (chromic catgut). Analisis data menggunakan independent t-test.

Hasil: Uji statistik menggunakan t-test independent untuk nyeri didapatkan hasil $p=0,035<0,05$ dan untuk penyembuhan luka didapatkan hasil $p=0,000<0,05$ dari kedua hasil tersebut dapat diartikan ada perbedaan penggunaan benang polyglactin 910 (vicryl rapide) dan benang chromic catgut terhadap nyeri perineum dan penyembuhan luka perineum pada ibu postpartum.

Kesimpulan: TPenggunaan benang vicryl rapide untuk perbaikan perineum atau penjahitan luka perineum dapat mengurangi nyeri perineum dan penyembuhan luka yang lebih baik dibandingkan dengan penggunaan pada benang chromik catgut.

Kata kunci: chromik catgut, nyeri, penyembuhan luka perineum, polyglactin 910, vicryl rapide.

Correspondence author. Amilya Pradita. Faculty of Health Science

Universitas Aisyiyah Yogyakarta. amilyapradita24@gmail.com

Received: March, 2019 Accepted: March, $2021 \quad$ Published: July, 2021 


\section{INTRODUCTION}

Women who give birth vaginally will undergo perineal laceration / trauma well as spontaneous tearing during childbirth physiological or surgical incision (episiotomy). Spontaneous rupture perineum perineal injuries that occur due to certain reasons without tearing or deliberate action. These injuries occur during delivery and usually irregular ${ }^{1}$. Perieneum rupture is one of the trauma that often affects women during childbirth. Perineal trauma and perineal repair is associated with puerperal resulting in morbidity such as bleeding, infection, pain, urinary and faecal incontinence and sexual dysfunction ${ }^{2}$. Other factors that can increase morbidity Other types of materials or stitches are used during repair of perineal ${ }^{3}$.

Suture material for perineal repair used can increase perineal pain in the short-term postchildbirth, thus required the use of suturing best to reduce perineal pain and repair of perineal trauma, so that will reduce the impact of shortterm ${ }^{4}$

Suture material for perineal repair is often used is chromic catgut. Chromic catgut is yarn types absorption (absorption), have tensile strength 17-21 days, 90-110 days old absorption ${ }^{5}$. Other thread types that are rarely used is vicryl rapide is a type of yarn absorption (absorption), has a tensile strength of 10-14 days, 42 days longer absorption ${ }^{6}$.

The use of suture materials are superior in addition to reducing perineal pain also can accelerate wound healing, such as research conducted by explains that the use of polyglactin 910 suture material (vicryl rapide) is an ideal suture material for perineal repair perineal pain that produces fewer and better wound healing compared to the use of chromic catgut suture material ${ }^{3}$.

Based on the above researchers are searching for related to "Comparative Use of polyglactin 910 (Vicry Rapide) and Chromic catgut Against Pain and Wound Healing perineum on Postpartum"

\section{METHODS}

The research is true experiment (randomized controlled trial) with a single blinding technique.
The population in this study were all postpartum mothers who birth at health centers and health centers Godean I Mlati II in Sleman. The sample in this study is a normal birth mothers who suffered wounds perineum and perineal suturing was done using 910 threads polyglactin (vicryl rapide) or chromic catgut. Sampling was done by consecutive sampling. The sample size in this study were 40 respondents (20 respondents intervention group, the control group of 20 respondents) with the inclusion criteria primigravida pregnant women who spontaneously vaginal delivery without complications or complications, Maternal with spontaneous rupture of 2 nd degree perineal and given lidocaine when suturing and mothers who do not smoke. This study were followed up for 15 days to see perineal wound pain and wound healing of the perineum. Measuring tool to see perineal pain using the NRS and wound healing using REEDA.

\section{RESULTS}

This research was conducted in two health centers in Sleman namely Puskesmas Puskesmas Mlati Godean I and II. The number of samples in this study were 40 respondents (20 respondents 20 respondents intervention group and the control group).

Table 1. Characteristics of Research Subjects

\begin{tabular}{|c|c|c|}
\hline $\begin{array}{l}\text { characteristics of } \\
\text { Respondents }\end{array}$ & $\begin{array}{c}\text { Intervention } \\
\text { group } \\
(\mathrm{N}=20), \%\end{array}$ & $\begin{array}{c}\text { Control group } \\
\left(\begin{array}{c}\mathbf{N}=20) \\
\%\end{array}\right.\end{array}$ \\
\hline \multicolumn{3}{|l|}{ Age (y.o) } \\
\hline \multicolumn{3}{|l|}{ Not at risk } \\
\hline $20-35$ & $19(95.0)$ & $19(95.0)$ \\
\hline \multicolumn{3}{|l|}{ Risk } \\
\hline$(<20$ and $>35)$ & $1(5.0)$ & $1(5.0)$ \\
\hline Total & $20(100)$ & $20(100)$ \\
\hline \multicolumn{3}{|l|}{ Last hemoglobin } \\
\hline Normal & $18(90.0)$ & $16(80.0)$ \\
\hline mild anemia & $2(10.0)$ & $4(20.0)$ \\
\hline Total & $20(100)$ & $20(100)$ \\
\hline \multicolumn{3}{|l|}{ Techniques suturing } \\
\hline $\begin{array}{l}\text { simple interrupted } \\
\text { simple interrupted and }\end{array}$ & $5(25.0)$ & $5(25.0)$ \\
\hline simple continuous & $15(75.0)$ & $15(75.0)$ \\
\hline Total & $20(100)$ & $20(100)$ \\
\hline \multicolumn{3}{|l|}{ Personal hygiene } \\
\hline Community Health Center & $10(50.0)$ & $10(50.0)$ \\
\hline SOP PHC Mlati II & $10(50.0)$ & $10(50.0)$ \\
\hline Total & $20(100)$ & $20(100)$ \\
\hline
\end{tabular}


Table 2. The Mean Perineal Pain and Healing Wounds

\begin{tabular}{lccc}
\hline Variables & Group & \\
\cline { 3 - 4 } & Days to- & $\begin{array}{c}\text { Intervention } \\
\text { Average }\end{array}$ & $\begin{array}{c}\text { Control } \\
\text { Average }\end{array}$ \\
\hline Wound & 1 & 4.15 & 5.30 \\
pain & 2 & 4.00 & 4.75 \\
perineum & 3 & 3.55 & 4,05 \\
& 4 & 2.90 & 3.65 \\
& 5 & 2.55 & 3.10 \\
& 6 & 2.00 & 2.60 \\
& 7 & 1.65 & 2.40 \\
& 8 & 1.40 & 2.05 \\
& 9 & 1.15 & 1.50 \\
& 10 & 0.70 & 1.35 \\
& 11 & 0.50 & 1.15 \\
Perineum & 12 & 0.30 & 0.70 \\
Wound & 13 & 0.15 & 0.35 \\
Healing & 14 & 0.05 & 0.15 \\
& 15 & 0.05 & 0.15 \\
& 1 & 4.75 & 5.65 \\
& 3 & 1.65 & 2.30 \\
& 5 & 0.35 & 1.90 \\
& 7 & 0,00 & 1.75 \\
& 9 & 0.00 & 0.20 \\
& 11 & 0,00 & 0.00 \\
& 13 & 0.00 & 0.00 \\
& 15 & 0,00 & 0.00 \\
\hline
\end{tabular}

Table 3. Comparison of Pain and Wound Healing Perineum Perineum

\begin{tabular}{|c|c|c|c|c|c|}
\hline & \multicolumn{2}{|c|}{ Group } & \multirow[t]{2}{*}{$\begin{array}{c}\text { Mean } \\
\text { Difference }\end{array}$} & \multirow[t]{2}{*}{ CI $95 \%$} & \multirow[t]{2}{*}{ P-value } \\
\hline & $\begin{array}{c}\text { Intervention mean } \\
\pm \mathrm{SD}\end{array}$ & $\begin{array}{c}\text { Control mean } \\
\pm \text { SD }\end{array}$ & & & \\
\hline $\begin{array}{l}\text { The perineum } \\
\text { pain }\end{array}$ & $25.10 \pm 11.253$ & $33.2512,311$ & -8.150 & $-15.700-0.600$ & 0.035 \\
\hline $\begin{array}{l}\text { Perineum Wound } \\
\text { Healing }\end{array}$ & $6.75 \pm 1.333$ & $11.30 \pm 1.455$ & -4.550 & $-5443-3.657$ & 0.000 \\
\hline
\end{tabular}

Results of research on Comparative Use of polyglactin 910 (Vicryl rapide) and Chromic catgut against Pain and Wound Healing perineum in Puskesmas Regency Sleman, it can be concluded use of polyglactin 910 (vicryl rapide) has a better effect on pain and wound healing of the perineum compared with the use of chromic catgut.

\section{DISCUSSION}

Based on the above table 1 showed that the characteristics of the respondents in the intervention group and controls by age in mind that almost all respondents are in the productive age and only 2 respondents who have a risky age. Respondents who experienced mild anemia in the intervention group as much as 2 respondents and in the control group as much as 4 respondents. Sewing techniques used for engineering disconnected in the intervention group and by 5 respondents in the control group by 5 respondents in the two health centers had more frequent use sewing techniques baste and disconnected. Comparison of the appropriate personal hygiene at the health center respondents SOP intervention group and the control group is the same, each of the 20 respondents according to SOP I godean health centers and 20 health centers of respondents according to SOP Mlati II.

Based on Table 2 above showed a mean value of the highest perineal pain scores in the intervention group, namely on day 1 with a mean value of 4.15 and the lowest on day 14 with a mean value of 0.05 , while the highest in the control group to- 1 with a mean value of 5.30 and the lowest on day -14 with a mean value of 0.15 . 
The results mean value for perineal wound healing in the intervention group highest on day 1 with a mean value of 4.75 and the lowest at day-7 is 0.00 . Whereas in the control group the highest average value on day 1 with a mean value of 5.65 and the lowest on day 11 with a mean value of 0.00 .

Based on Table 3. The test results independent t-test can be concluded that perineal pain and healing wounds in the intervention group mean values of 25.10 and 6.75 , whereas in the control group mean values of 33.25 and 11.30. The test results using statistical tests obtained independent t-test $p$-value $<0.05$, which means that there are differences in the use of threads polyglactin 910 (vicryl rapide) and chromic catgut thread to perineal pain and healing wounds in the mother postpartum perineum.

This is according to research conducted by explains that the use of suture material with polyglactin 910 (Vicryl rapide) superior than chromic catgut. polyglactin 910 (Vicryl rapide) can be absorbed naturally and may reduce pain compared with the use of chromic catgut sutures ${ }^{7}$. Also in line with research explained that the use of polyglactin 910 suture material (vicryl rapide) is an ideal suture material for perineal repair perineal pain that produces fewer and better wound healing compared to the use of chromic catgut suture material ${ }^{8}$.

Explains that the use of thread vicryl rapide produces less pain and better wound healing ( $p$ $<0.05$ significant) ${ }^{9}$. In concluded that vicryl rapide better at reducing pain and wound healing in wound repair perineum.

Explained that the use of vicryl suture materials rapide there is a significant reduction in short-term pain ${ }^{10}$. The pain began to improve from the third day onwards, no experience moderate pain on day 7 and on day 15, no woman who complained of pain in the group vicryl rapide compared with chromic catgut were still experiencing mild pain on day 15. From day 7 onwards perception of pain was lower in the group vicryl rapide compared with chromic catgut

\section{CONCLUSION}

All in all, vicryl rapide thread to repair perineum or perineal wound suture is more effective to reduce perineal pain and has better perineal wound healing than chromic catgut thread. Health workers are suggested to choose the right material of thread in perineal repair in order to reduce pain and speed up the process of perineal wound healing in postpartum mothers with perineal rupture

\section{REFERENCES}

1. Abu Seada, M. R., Borg, T. F., \& Samy, M. M. Continuous versus Interrupted Suturing in Repair of Lateral and Mediolateral Episiotomy: A Randomized Controlled Trial. Egy J Hos Med. 2018; 71: 2667-80.

2. Gray, E. Suturing versus non-suturing of spontaneous perineal tears following normal birth: Factors that influence the practice of New Zealand / Aotearoa midwives. 2010:10.

3. Bharathi, A., Dharma Reddy, DB, \& Sharath Kote, GS. A prospective randomized comparative study of vicryl rapide versus chromic catgut for episiotomy repair. J Clin Diagnos Research. 2013; 7: 326-30.

4. Kettle C, D. T. Continuous and interrupted suturing techniques for repair of episiotomy or second-degree tears. The Cochrane Database of Systematic Reviews. 2012; 11: CD000947.

5. Dudley, L., Kettle, C., \& Ismail, K. Prevalence, pathophysiology and current management of dehisced perineal wounds following childbirth. Bri J Midwifery. 2013; 21: 160-71.

6. Abdullah, M., Noreen, A., Iqbal, M., \& Sohail, R. Comparison Between Chromic Catgut and Vicryl Rapide for Analgesia Requirement in episiotomy Repair in Primigravidas. 2015; 21: 193-6.

7. Samant, M., Bose, E., Ghosh, A. Lal, P., \& Mishra, S. Comparison of the impact of polyglactin 910 (Vicryl rapide) and chromic catgut sutures on perineal pain following episiotomy wound repair in the eastern Indian Patients. J Scien Soc. 2013; 40: 95.

8. Perumal, D., \& Selvaraju, D. Comparative study of episiotomy repair: versus synthetic absorbable chromic catgut suture material. Int J Reprod Contracept Obstet Gynecol. 2017; 6: 2186.

9. Esa B., M. Samant, P. Lal, S. Mishra, Ghost A. Comparison of the impact of polyglactin 910 (Vicrylrapide) and chromic catgut sutures on perineal pain following episiotomy wound repair in the eastern Indian Patients. J Scien Soc. 2018; 40.

10. Odijk, R., Hennipman, B., Rousian, M., Madani, K., Dijksterhuis, M., de Leeuw, J. W., \& van Hof, A. The MOVE-trial: Monocryl ${ }^{\circledR}$ vs. Vicryl rapideTM for skin repair in mediolateral episiotomies: $\mathrm{A}$ randomized controlled trial. BMC Pregnancy and Childbirth. 2017; 17: $1-7$ 